\title{
An Action Research on Enhancing Grade 10 Student Creative Thinking Skills using Argument-driven Inquiry Model in the Topic of Chemical Environment
}

\author{
Pitukpong Kumdang1*, Sirinapa Kijkuakul ${ }^{1}$, Wipharat C. Chaiyasith ${ }^{2}$ \\ ${ }^{1}$ Faculty of Education, Naresuan University, Tha Pho, Mueang Phitsanulok District, Phitsanulok 65000, Thailand \\ ${ }^{2}$ Faculty of Science, Naresuan University, Tha Pho, Mueang Phitsanulok District, Phitsanulok 65000, Thailand \\ *Corresponding Author. pitukpongk59@,email.nu.ac.th
}

\begin{abstract}
A goal of the $21^{\text {st }}$-century education is to enhance students' creative thinking skills as the basis for construction of innovations for developing countries. Generally, previous teaching tradition, teacher-centered approach, are used in many classrooms, however, failed the goal. Therefore, this study aims to promote Grade 10 Thai students' creative thinking by implementing Argument-Driven Inquiry (ADI) through three cycles of action research. There are 31 students participated in the study. The student data are collected using learning journals, artifacts and informal interviews then analyzed with content analysis and method triangulation. The findings indicate that students have a progression in creative thinking. They can develop skills of curiosity, originality, fluency, imagination, elaboration, and flexibility respectively. As a recommendation, it is necessary that teaching for that success needs integrations among chemical environment, geography, and art.
\end{abstract}

Keywords Creative Thinking Skills, Argument-driven Inquiry, Action Research

\section{INTRODUCTION}

"Framework for 21 2 st Century Learning" was developed by Partnership for $21^{\text {st }}$ Century Skills (P21) to prepare all students for living in today's and tomorrow's world, for this framework students should have skills of creativity and innovation, critical thinking and problem solving, communication, and collaboration to succeed in work and life in the $21^{\text {st }}$ century world (P21, 2017). Meaningfully, the most important skill is creative thinking that is a basis for construction of innovations for developing countries. Organization for Economic Cooperation and Development (OECD) that implemented the project in the name of "Teaching, assessing and learning creative and critical thinking skills in education", also supported that the creative thinking skills should be aimed at a goal of education for present day and future generations (Stéphan, 2017). Nowadays, creative thinking skills are perceived as a group of six sub-skills including an alternative idea or originality, fluency, flexibility, elaboration, curiosity, and imagination (Greenstein, 2012).

From the pilot study in a special science classroom in Lower North area school of Thailand, most teachers were familiar with the traditional teaching approach, teachercentered of learning, focused on scientific contents. The school tended to appreciate rote learning for passing examination rather than active learning for using knowledge in real life situations. Evidence was found in grade 10 classroom observations. The teacher appeared to use closed-ended questions which had a single answer or a single method to launch understandings of atomic theory, for example. The students were not promoted to meaningfully deep learning and linking between scientific concepts and things around them (Thompson, 2017). Even though reflection is a critical part of the creative process (Resnick \& Mitchel, 2007), the students were not familiar with reflecting themselves after work. As the results, the students had little competency in creative thinking skills. This situation strongly indicated that the traditional teaching approach was blocking the creative thinking skills of students.

One of the effective approaches that possibly promotes creative thinking skills is learning through scientific argumentation approach. Generally, argumentation is known as a social activity of at least two parties, e.g. two

Received: 16 July 2018

Revised: 4 September 2018

Published: 3 December 2018 
Table 1 Example of categories and codes.

\begin{tabular}{|c|c|c|c|}
\hline Categories & Codes & Definitions/levels & Sample \\
\hline \multirow[t]{4}{*}{ Fluency } & Flu1 & Level 1: No variety or perspective & $\begin{array}{l}\text { S1315: "Energy shortage will happen when the non- } \\
\text { renewable energy is low." }\end{array}$ \\
\hline & Flu2 & $\begin{array}{l}\text { Level 2: Some variety but unclearly } \\
\text { perspective }\end{array}$ & $\begin{array}{l}\text { S2321: "Renewable energy could be endless.", "Renewable } \\
\text { energy is still limited in use." }\end{array}$ \\
\hline & Flu3 & $\begin{array}{l}\text { Level 3: Some variety and clearly } \\
\text { describe the perspective }\end{array}$ & $\begin{array}{l}\text { S2317: "The area has a lot of wind or solar would be } \\
\text { appropriate, it will help to generate energy" }\end{array}$ \\
\hline & Flu4 & $\begin{array}{l}\text { Level 4: Many varieties and clearly the } \\
\text { perspective }\end{array}$ & $\begin{array}{l}\text { S2308: "Chat-trakan district should be suited to renewable } \\
\text { energy sources because of the high mountain area, and } \\
\text { strong wind." }\end{array}$ \\
\hline
\end{tabular}

groups of students, to present the process of constructing a logical explanation that needs theory and empirical evidence to support for making a group decision and accepting or rejecting any claims (Van Eemeren, 1995). In other words, the argumentation seems like convincing other people through credible communication and spoken and written proof (Erduran, 2007; Kuhn \& Udell, 2011). Moreover, scientific argumentation represents an attempt to establish the validity of the claims that require reasoning skill (Norris, Philips, \& Osborne, 2007) and scientific's conceptions. The scientific argumentation is not shouting to fight each other but it is a dispute involved understanding scientific knowledge, demonstrating personal perspective towards circumstances or claims. The scientific argumentation is also framing students to practice critical thinking and creative thinking skills in order to give appropriate scientific reasons to support the claims (Berland \& Reiser, 2011). As mentions above, the process of constructing scientific argumentation possibly promotes the student's creative thinking skills.

Therefore, the researcher aims to implement the effective approach base on scientific argumentation to promote creative thinking skills of grade 10 students in the topic of chemical environment.

\section{METHOD}

\subsection{Participants}

Thirty-one students in the $10^{\text {th }}$-grade classroom, in Phitsanulok province in Thailand, had participated in the study. There were three fifty-minute periods of teaching per week, and they had a lot of learning facilities in the school such as Wi-Fi, laptops, and smartphones. Also, student parents were willing to support all aspects related to student learning, e.g. stationery, technology, and payment.

\subsection{Action Research}

This study implemented action research as a method to develop own teaching practice within conditions of the $10^{\text {th }}$-grade classroom. Basically, action research is a spiral process of practices solving a particular problem (Kemmis, Mc'Taggart, \& Nixon, 2014). The process consists of 4 steps: 1) plan, 2) action, 3) observation, and 4) reflection (Kemmis, 2009) as Figure 1.

\subsection{Argument-Driven Inquiry (ADI) Model}

This study used the principles of Argument-Driven Inquiry (ADI) of the previous studies (Sampson \& Grooms, 2010; Sampson, Grooms, \& Walker, 2011; Sampson \& Walker, 2012) that concerned scientific argumentation approach. Generally, ADI is a teaching model emphasizes student-centered learning. It provides students with more opportunities to construct knowledge and scientific explanations through self-inquiry. By teacher facilitation, students learn how to develop an approach for generating data, carrying out an investigation, and simplifying data to answer a problematic issue, as well as reflecting own work and others. In this study, the researcher adaptively implemented the ADI principle as the following steps: 1) to identify tasks base on a problematic issue; 2) to plan and design how to investigate data; 3) to analyze data and develop a tentative argument; 4) to present the tentative argument of each group as a group work; 5) to collaboratively revise that argument and then create final argument; 6) to create group artifacts and individual learning journals; and 7) to revise the final report. This AID model was modified through three cycles of action research, for three weeks.

\subsection{Research Instruments and Data Collection}

The student data were collected using the artifacts, informal interviews and learning journals. Each week of the ADI implementation, the students were assigned to create an artifact, i.e. a poster, a model and a painting, to solve environmental issues. Before the students would create the artifact, they were challenged to inquire

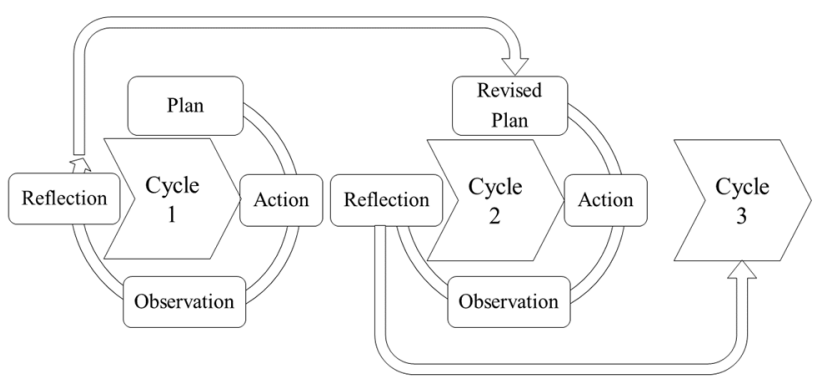

Figure 1 Research process of action research 


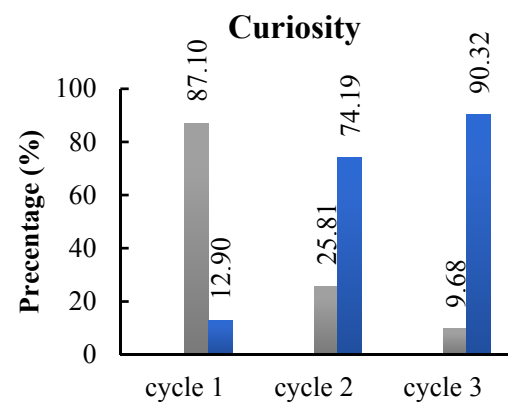

Flexibility

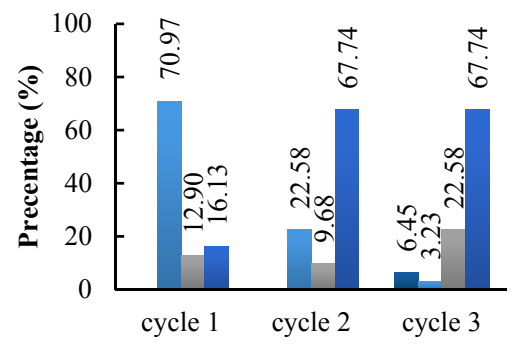

Figure 2. Students' creative thinking skills
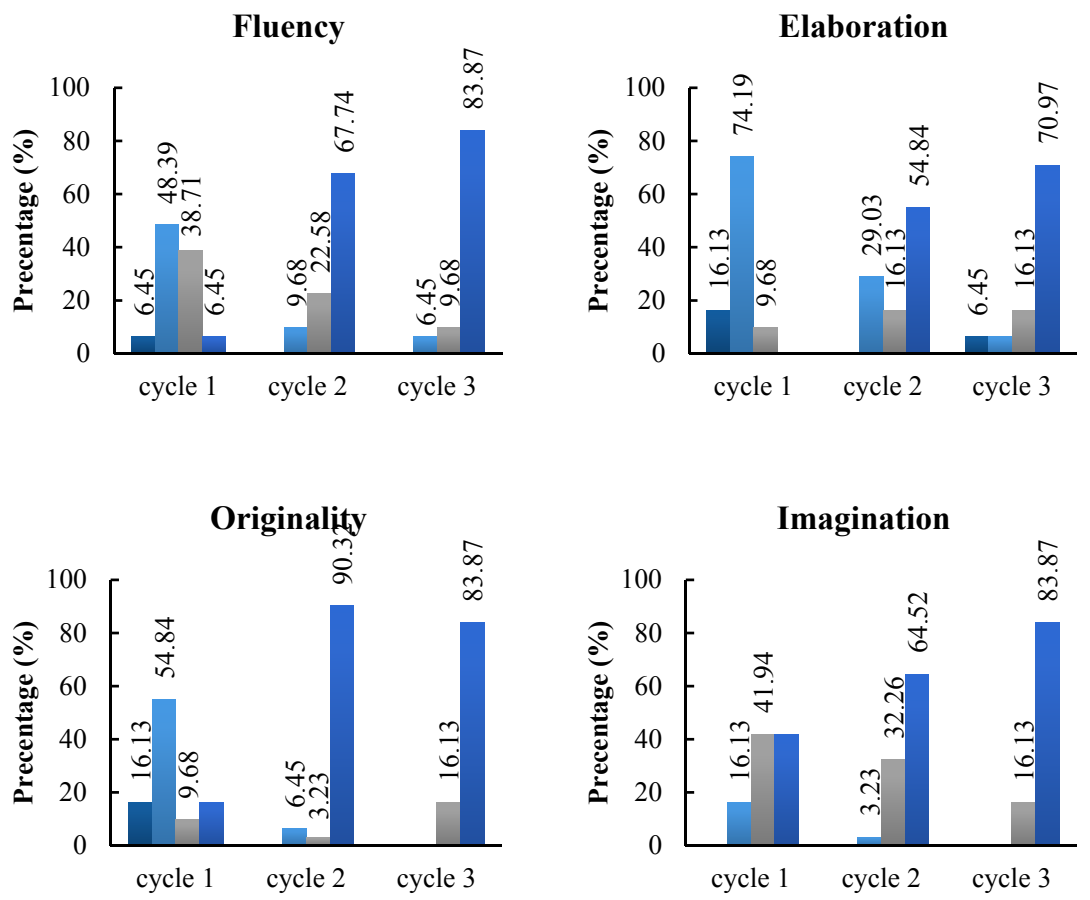

knowledge and data in the account to the steps of the ADI model. During class, the researcher, as a participant observer, checked and reflected the students' inquiry through informal interviews. They also were asked to illustrate what they learned in the learning journal.

\subsection{Data analysis}

This study analyzed the student data using content analysis method. It is the way to search for the truth by making inference about non-definite features of the content through definite features of the fact. The method is used to gain replicable and valid results from the data regarding its content (Krippendorff, 2013). Table 1 shows examples of data categories and codes constructed by the analysis of the learning journals and artifacts. This study also used method triangulation for trustworthiness. Consequently, the student creative thinking skills would be arranged into 4 levels as definitions in Table 1. In addition, the skill was identified as six sub-skills including originality, fluency, flexibility, elaboration, curiosity, and imagination. The results will be shown in the next section.

\section{RESULT AND DISCUSSION}

The findings of the study revealed that adaptively implementation of ADI model in the chemical environment topic was more effective in improving the students' creative thinking skills. Figure 2 provides information about the percentage of students who developed creative thinking skills in each level of progression from cycle 1 to cycle 3 .

As an overview in cycle 1, most students (41.94\%) illustrated their progression in the imagination at level 4 . In the classroom observation, when the students were asked to create the final argument, they acted like an environmentalist who designed and created a poster to encourage people to use renewable energy. A group of students, for example, showed their imagination through the created poster (figure 3). Their perspective on the situation of increasing temperature in the world is presented by the picture of a fried-earth egg that is being heated. This requests that people need to think about

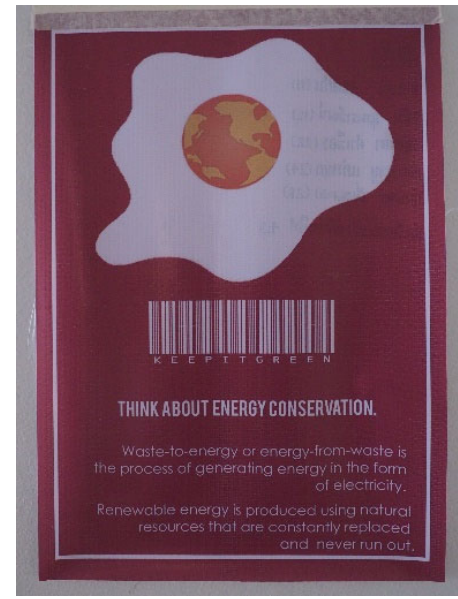

Figure 3 Example of the poster. 
energy conservation and suggests that people should turn to use renewable energy. This result is in line with Thompson's study (2017) which indicated that the "realworld" situations which are meaningful problems in ADI model can promote student's imagination.

In addition, some students (more than 12\%) were equally found to achieve in three sub-skills, flexibility, originality and curiosity, but only one student $(6.45 \%)$ had development in the sub-skill of fluency. There had no student achieving in the sub-skill of elaboration. It was possible that this less achievement appeared because the students were familiar with the traditional teaching approach yet. So, when they were challenged with a problematic issue, they were confused and felt that selfinquiry was hard to practice. Examples from the students' questions in informal interviews indicated that some students had no ideas how to inquire knowledge: "what should I do before starting the investigation?" (S01) and "How should I set the objective to explore?" (S02). Moreover, the previous study supported that development of elaboration skill depended on students' achievement in the skill of originality and competency in self-reflection. If students had no high achievement in the originality and could not reflect themselves, they seemed to have less ability in the elaboration (Greenstein, 2012).

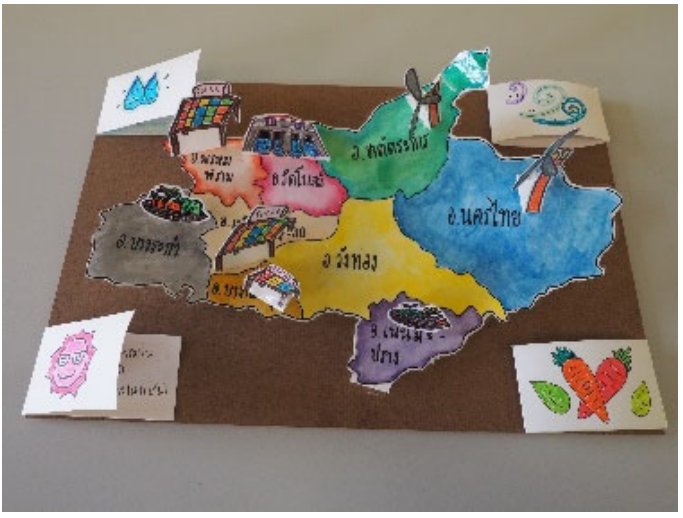

Figure 4 An example of the model.

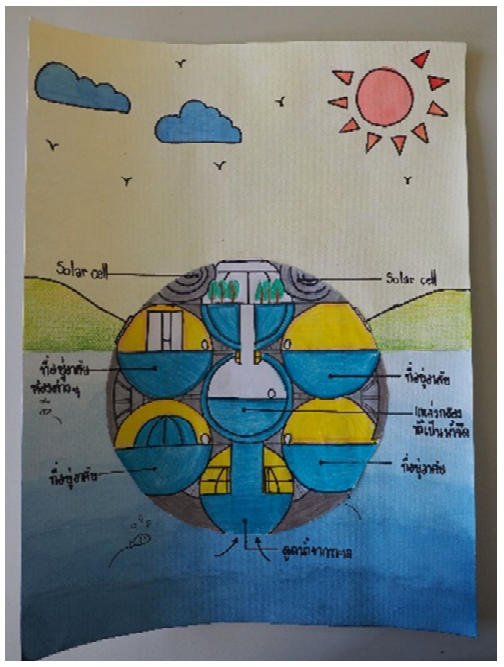

Figure 5 An example of painting.
Cycle 2, all six sub-skills were increased dramatically. Most students had highly achieved in level 4 of the originality $(90.32 \%)$, curiosity $(74.19 \%)$, flexibility $(67.74 \%)$, fluency $(67.74 \%)$, imagination $(64.52 \%)$ and elaboration $(57.84 \%)$. The students' learning journal revealed their progression that they could identify problematic tasks into complexed questions as follows: "What are types of renewable energy?", "Which area in Phitsanulok province could be built as a power factory from renewable energy?", and "Why do I use that area?" (S03). Also, the student's model (figure 4) was another evidence of the increase of originality, imagination, flexibility, and fluency. As the study of Resnick \& Mitchel (2007, p.3) showed that "create" is at the root of creative thinking. If we want the student to develop their creative thinking skills, we need to provide them with more opportunities to create. There, they developed the final arguments to create the model that showed the possibility of building the power factory in the area.

Cycle 3, when looking at the graphs as a whole, development of the students' creative thinking skills is continued on the way of implementing the ADI model. This study found that the students had significantly changed in the development of curiosity $(90.32 \%)$. From the students' learning journals, most students could create complexed questions to guide self-solution of problematic tasks. In classroom observation, the students often appeared to discuss with their group and others. Perhaps these performances led them to have more development of curiosity than what they used to do in cycle 1 and 2 .

In addition, more than eighty percentages of students also had development in the sub-skills of fluency, originality, and imagination. As evidence from classroom observation, the students were challenged to create their residences for living in the two-degree warmer world. Such a result, the students illustrated the originality and imagination through the painting (figure 5). They presented a high technology capsule as their residences which can change seawater to be drinking water and produce food by themselves.

After three cycles of action research, this study found that most students had higher development in selfreflection. This meaningful reflection causes them to have rapid progression in the development of the elaboration which is consisted of creative thinking skills. For example, a student (S03) strongly supported that “...our reflections enabled me to improve myself and I would use this strategy for my future work.". This critical reflection shows the design or strategies can help the student improve their creative thinking skill (Resnick \& Mitchel, 2007). It is also in line with the study of Awang \& Ramly (2008) which stated that: "Creative skills must be practiced until the thought patterns in our minds become comfortable with these creative lateral thinking techniques. We can create these creative grooves in our mind so these techniques will 
be utilized. This also can help students produce better, more satisfying and more creative." Additionally, if the students are provided the opportunities to continuously create an artifact together through self-reflection, this strategy could help the student to improve their all subskills of creative thinking skills.

\section{CONCLUSION}

Implementation of the modified ADI model in Thailand developed the students' all sub-skills of creative thinking including curiosity, originality, fluency, imagination, flexibility, and elaboration respectively. The curiosity had the most progression in the context of the chemical environment, and this curiosity is the basis of learning other sub-skills. After some consideration on the ADI model, this study suggested that the priority of teaching is challenging students to identify tasks in the account to problematic issues. This would promote the students' curiosity. Also, teachers need to encourage students to reflect themselves in every activity of the ADI model. This would help students to further other subskills. In addition, implementation of the ADI model need time so much, so this would be better if teachers could integrate the topic of the chemical environment with other subjects, e.g. geography and art.

\section{ACKNOWLEDGMENT}

I would like to thank the Faculty of education, Naresuan University and the Institute for the Promotion of Teaching Science and Technology (IPST) which supported me for the scholarship to expand my horizons in the education field. Foremost, I would like to express my gratitude to my supervisor and supervising teacher for the motivation and support. Lastly, I thank my friends for facilitating and supporting me throughout the process of this study.

\section{REFERENCES}

Awang, H., \& Ramly, I. (2008). Through Problem-Based Learning: Pedagogy and Practice in the Engineering Classroom. International Journal of Human and Social Sciences, 2(4), 18-23.

Berland, L. K., \& Reiser, B. J. (2011). Classroom communities' adaptations of the practice of scientific argumentation. Science Education, 95(2), 191-216. https://doi.org/10.1002/sce.20420
Erduran, S. (2007). Methodological foundations in the study of argumentation in science classrooms. Argumentation in science education.

Greenstein, L. (2012). Assessing 21st century skills: a guide to evaluating mastery and authentic learning. Corwin Press.

Kemmis, S. (2009). Action research as a practice-based practice. Educational Action Research, 17(3), 463-474. https://doi.org/10.1080/09650790903093284

Kemmis, S., McTaggart, R., \& Nixon, R. (2014). The action research planner: doing critical participatory action research. singapore.

Krippendorff, K. (2013). Content analysis: an introduction to its methodology. SAGE.

Kuhn, D., \& Udell, W. (2011). The development of argument skills. Child Development, 74(5), 1245-60. https://doi.org/10.1111/14678624.00605

Norris, S., Philips, L., \& Osborne, J. (2007). Scientific inquiry: The place of interpretation and argumentation. Science as Inquiry in the Secondary Setting. $\quad$ Retrieved from http://www.nsta.org/store/download.aspx?l=8JgS7/JBvFIPibfC 0TL4iw $==$

P21 partnership for 21st century learning-Creativity and Innovation. (n.d.). Retrieved September 8, 2017, from http://www.p21.org/about-us/p21-framework/262

Resnick, M., \& Mitchel. (2007). All I really need to know (about creative thinking) I learned (by studying how children learn) in kindergarten. In Proceedings of the $6^{\text {th }}$ ACM SIGCHI conference on Creativity \& cognition - C\&C '07 (pp. 1-6). New York, USA: ACM Press. https://doi.org/10.1145/1254960.1254961

Sampson, V., \& Grooms, J. (2010). Generate an argument: An instructional model. The Science Teacher, 77(5), 32-37. Retrieved from

http://search.proquest.com/openview/0abe26442b84981b65eda c230 $\operatorname{cccd} 331 / 1$ ?pq-origsite $=$ gscholar\&cbl $=40590$

Sampson, V., Grooms, J., \& Walker, J. P. (2011). Argument-Driven Inquiry as a way to help students learn how to participate in scientific argumentation and craft written arguments: An exploratory study. Science Education, 95(2), 217-257. https://doi.org/10.1002/sce.20421

Sampson, V., \& Walker, J. P. (2012). Argument-Driven Inquiry as a Way to Help Undergraduate Students Write to Learn by Learning to Write in Chemistry. International Journal of Science Education, 34(10), 1443-1485. https://doi.org/10.1080/09500693.2012.667581

Stéphan, V.-L. (n.d.). Teaching, assessing and learning creative and critical thinking skills in education. Retrieved October 13, 2017, from

http://www.oecd.org/education/ceri/assessingprogressionincrea tiveandcriticalthinkingskillsineducation.htm

Thompson, T. (2017). Teaching Creativity Through Inquiry Science. Gifted Child Today, 40(1), 29-42. https://doi.org/10.1177/1076217516675863

Van Eemeren, F. H. (1995). A world of difference: The rich state of argumentation theory. Informal Logic, 17(2), 144-158. 